\title{
FORMULATION AND EVALUATION OF TRANSDERMAL PATCHES OF METOPROLOL SUCCINATE
}

\section{Indresh}

Research Scholar, Mahatma Gandhi College of Pharmaceutical Sciences Jaipur, Rajasthan, India

Article Info: Received 13 January 2020; Accepted 14 February 2021

DOI: https://doi.org/10.32553/jbpr.v10i1.837

Corresponding author: Indresh

Conflict of interest statement: No conflict of interest

\begin{abstract}
The anti-hypertensive transdermal patches in the perspective of enhancing the bioavailability as well as in improving patient compliance, it has appear as a substitute for oral route permit self-administration, controlled and sustained drug delivery. This study will investigate the effects of metoprolol Succinate in treatment of hypertension with the interaction of hydroxy propyl methyl cellulose and ethyl cellulose. The present research work concludes that the patches prepared with different ratios of polymers shows sustained drug release for long period of time confirms that the delivery system prepared can be suitably used as sustained and controlled drug delivery. The Transdermal Patches of drug metoprolol Succinate can be utilized in the diseases hypertension, myocardial infarction and congestive heart failure, etc. It offers high patient compliance by ease in administration.
\end{abstract}

Keywords: Anti-hypertensive, Transdermal patches, Metoprolol succinate and HPMC.

\section{Introduction}

Hypertension is the chronic elevation of blood pressure that, in the long term, causes and and organ damage \& results in increased morbidity and mortality occurs due to the abnormal functioning of the arterial pressure related to the central nervous system [1], rennin-angiotensin-aldosterone system endothelial dysfunction, genes and even due to certain environmental factors.

The basic component of Transdermal Drug Delivery System [2] includes inert polymer matrix in which the drug is dissolved or dispersed providing support \& platform for drug release. There are Two basic designs of the patch system;
- Matrix or Monolithic: The polymer matrix [3] holds a large quantity of drug and controls the release from the device.

- Reservoir or Membrane: The rate controlling membrane [4] made of a polymer present between the drug layer and the adhesive layer that provides the rate limiting barrier for drug release from the device.

Many of the technologies have been successfully developed to provide the rate control over the release and skin permeation of drugs [5].

\section{Materials and Methods:}

Materials:

Table 1: List of Ingredients

\begin{tabular}{llll}
\hline S. No. & Name & Specification & Manufacturer \\
\hline 1. & Metoprolol Succinate & Pharma Grade & Bal Pharma Ltd. Rudrapur \\
\hline 2. & Hydroxy Propyl Methyl Cellulose & Analytical Grade & Classic Solvent PVT. LTD, Ahmedabad \\
\hline 3. & Ethyl Cellulose & Analytical Grade & Galaxy Chemicals, Ahmedabad \\
\hline 4. & Eudragit-L 100 & Analytical Grade & Bal Pharma Ltd. Rudrapur \\
\hline 5. & Dibutyl Phthalate & Analytical Grade & Merk, Mumbai \\
\hline 6. & Dimethyl Sulphoxide & Analytical Grade & Merk, Mumbai \\
\hline 7. & Methanol & Analytical Grade & S. D. Fine Chemicals, Ahmedabad \\
\hline 8. & Dichloromethane & Analytical Grade & SolvoChem, Ahmedabad \\
\hline
\end{tabular}




\section{Methods:}

Preparation of Phosphate buffer (pH 6.8): 27.216 gm of Potassium dihydrogen phosphate $\left(\mathrm{KH}_{2} \mathrm{PO}_{4}\right)$ was taken and dissolved in $200 \mathrm{ml}$ of distilled water. To make $0.2 \mathrm{M} \mathrm{KH}_{2} \mathrm{PO}_{4}$. the volume was made upto $1000 \mathrm{ml}$ with distilled water. Further 8 gms of Sodium hydroxide $(\mathrm{NaOH})$ was taken and dissolved in $200 \mathrm{ml}$ of distilled water [6] to make $0.2 \mathrm{M} \mathrm{NaOH}$ the volume was made upto $1000 \mathrm{ml}$ with distilled water. To make Phosphate buffer $\mathrm{pH}$ $6.8,250 \mathrm{ml}$ of $0.2 \mathrm{M} \mathrm{KH}_{2} \mathrm{PO}_{4}$ and $112 \mathrm{ml}$ of $0.2 \mathrm{M}$ $\mathrm{NaOH}$ was mixed and the volume was made upto $1000 \mathrm{ml}$ with distilled water.

Determination of $\lambda_{\max }$ : The UV spectrum of Metoprolol succinate was analyzed spectrophotometrically by using spectrophotometer (UV-1800 Shimadzu). $100 \mathrm{mg}$ of the drug was accurately weighed and dissolved in sufficient quantity of Phosphate buffer ( $\mathrm{pH}$ 6.8) and the final volume was made up to $100 \mathrm{ml}$ to prepare the stock solution of solution of $1000 \mu \mathrm{g} / \mathrm{ml}$. From the stock solution $1 \mathrm{ml}$ was withdrawn and volume was made up to $100 \mathrm{ml}$ with Phosphate buffer to obtain the solution of $10 \mu \mathrm{g} / \mathrm{ml}$ [7]. The resultant solution was scanned from 200 to $400 \mathrm{~nm}$ and the spectrum was recorded to obtain maximum wavelength $\lambda_{\text {max. }}$

Preparation of Calibration Curve of Metoprolol succinate in phosphate buffer (pH 6.8):100 mg of Metoprolol succinate [8] was accurately weighed and dissolved in sufficient quantity of phosphate buffer ( $\mathrm{pH}$ 6.8) and the final volume was made up to $100 \mathrm{ml}$ to prepare the stock solution of solution of $1000 \mu \mathrm{g} / \mathrm{ml}$. From the stock solution $1 \mathrm{ml}$ was withdrawn and volume was made up to $10 \mathrm{ml}$ with phosphate buffer to obtain the solution of $100 \mu \mathrm{g} / \mathrm{ml}$. This solution was further diluted to prepare solutions of $5 \mu \mathrm{g} / \mathrm{ml}$ to $30 \mu \mathrm{g} / \mathrm{ml}$. Absorbances of each solution was measured at $223 \mathrm{~nm}$ [9] using Shimadzu UV-1800 Spectrophotometer using $\mathrm{pH}$ 6.8 phosphate buffer as a reference standard. The calibration curve was prepared for solutions of $5 \mu \mathrm{g} / \mathrm{ml}$ to $30 \mu \mathrm{g} / \mathrm{ml}$.

\section{Compatibility studies:}

FT-IR Spectroscopy: FT-IR spectroscopy was employed to ascertain the compatibility the drug Metoprolol Succinate and the selected polymers, FT-IR spectra of pure drug Metoprolol succinate was taken separately [10]. Further drug and polymers (HPMC and Ethyl cellulose) were mixed in the same ratio as shown in table 2 and scanned using Shimadzu FT-IR.

Table 2: Drug Polymer ratio for Compatibility studies

\begin{tabular}{lll}
\hline S. No. & Drug-Excipient & Ratio \\
\hline 1. & Metoprolol succinate: HPMC & $1: 1$ \\
\hline 2. & Metoprolol succinate: $E C$ & $1: 1$ \\
\hline 3. & Metoprolol succinate: HPMC: $E C$ & $1: 1: 1$ \\
\hline
\end{tabular}

Formulation of Transdermal Patches:

Transdermal Patches of Metoprolol Succinate were prepared by solvent evaporation method. The polymer ethyl cellulose \& HPMC were taken in required amount. About $20 \mathrm{ml}$ of solvent mixture of methanol:dichloromethane in the ratio of $1: 1$ was added and stirred well. When the polymers completely solublized in mixture of solvent, added $0.5 \mathrm{ml}$ dibutylphthlate act as a plasticizer [11]. Then added 50mg of the drug metoprolol succinate to the polymer solution and finally added the $0.2 \mathrm{ml}$ of permeation enhancer dimethyl sulphoxide. This mixture was placed at one side for sometime to exclude any entrapped air and was then transferred into a previously cleaned and dried petri plate. Then the plate was kept a side for solvent evaporation and was covered by funnel to control evaporation of solvent. Allowed to dry at room temperature overnight [12], The dried films were separated and the backing membrane used was aluminium foil and stored in desiccators These films were further evaluated.

Table 3: Composition of Transdermal Patches of Metoprolol Succinate

\begin{tabular}{llllll}
\hline Formulation & F1 & F2 & F3 & F4 & F5 \\
\hline Drug $(\mathrm{ms})(\mathrm{mg})$ & $50 \mathrm{mg}$ & $50 \mathrm{mg}$ & $50 \mathrm{mg}$ & $50 \mathrm{mg}$ & $50 \mathrm{mg}$ \\
\hline HPMC & $500 \mathrm{mg}$ & $450 \mathrm{mg}$ & $400 \mathrm{mg}$ & $350 \mathrm{mg}$ & $300 \mathrm{mg}$ \\
\hline Ethyl Cellulose & $500 \mathrm{mg}$ & $550 \mathrm{mg}$ & $600 \mathrm{mg}$ & $650 \mathrm{mg}$ & $700 \mathrm{mg}$ \\
\hline Dibutylphthalate & $0.5 \mathrm{ml}$ & $0.5 \mathrm{ml}$ & $0.5 \mathrm{ml}$ & $0.5 \mathrm{ml}$ & $0.5 \mathrm{ml}$ \\
\hline Dimethylsulphoxide & $0.2 \mathrm{ml}$ & $0.2 \mathrm{ml}$ & $0.2 \mathrm{ml}$ & $0.2 \mathrm{ml}$ & $0.2 \mathrm{ml}$ \\
\hline Methanol: Dichloromethane & $1: 1$ & $1: 1$ & $1: 1$ & $1: 1$ & $1: 1$ \\
\hline
\end{tabular}


Evaluation of transdermal patches of metoprolol succinate:

The physicochemical evaluation of transdermal patches is based on following parameters;

Physical Appearance: All the prepared Transdermal Patches were observed visually for colour, clarity, smoothness and flexibility [13].

Surface PH Measurement: The $\mathrm{pH}$ of prepared transdermal patches was measured with the help of calibrated $\mathrm{pH}$ meter. The average of three readings was recorded for patch [13, 14].

Thickness of Patch: The thickness of each transdermal patch was measured at six different places using a digital vernier calliper and average thickness of patches was measured [11, 14].

Weight Uniformity: The three different patches from each formulation weighed on electronic weighing balance and calculated the average weight of three patches. The individual weight should not deviate from the average weight of patch [15].

Folding Endurance: This test is done to determine the following capacity of the patches subjected to frequent extreme conditions of folding [16]. The folding endurance was determined by repeatedly folding a small strips of films at the same place till it broke.

Flatness: Three longitudinal patches were cut from each patch at different portion like centre, left, and right side. The initial length of strip was measured and then kept for two hours at room temperature. The variations in length due to non uniformity in flatness were measured by determing percent constriction by using the following formula [17]-

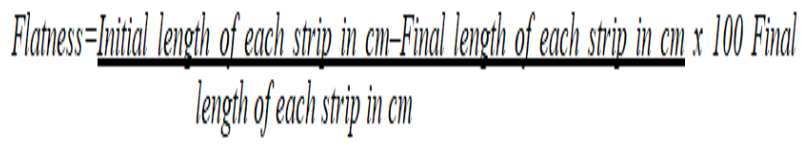

Percentage Moisture Loss: The percentage moisture loss test is used to check the integrity of transdermal patches at drug condition. Accurately weighed of three $1 \mathrm{~cm}$ patches were kept in dessicators containg anhydrous calcium chloride [18] and exposed to an atmospheric room temperature.

\section{$\%$ Moisture Loss = Initial weight-Final weight $X 100$ Final weight}

Percentage Moisture Absorption: The Percentage Moisture Absorption test is carried out to check the physical stability of trandermal patches at high humid conditions. The weight of three $1 \mathrm{~cm}$ patches were weight accurately and then placed in dessicators containing saturated solution of potassium chloride, with the relative humidity $84 \%$ $[18,19]$. The patches were removed after three days, weight and Percentage Moisture Absorption was calculated by the following formula-

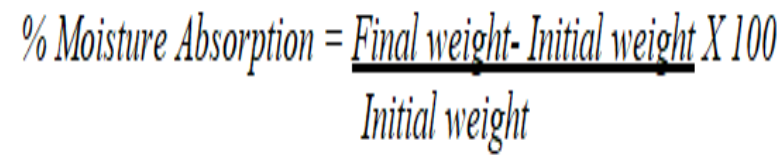

Tensile Strength: To determine tensile strength, polymeric films are sandwiched separately by corked linear iron plates. One end of the films is kept fixed with the help of an iron screen and other end is connected to a freely movable thread over a pulley. The weights are added gradually to the pan attached with the hanging end of the thread. A pointer on the thread is used to measure the elongation of the film [17, 19]. The weight just sufficient to break the film is noted. The tensile strength can be calculated using the following equation.

Tensile strength $=F / a \cdot b(1+L / l)$

$\mathbf{F}$ is the force required to break; $\mathbf{a}$ is width of film; $\mathbf{b}$ is thickness of film; $\mathbf{L}$ is length of film; $\mathbf{l}$ is elongation of film at break point.

Water Vapour Permeability: Glass vials of the same diameter were washed thoroughly and dried to a constant weight in an oven. About $1 \mathrm{gm}$ of fused Calcium chloride was taken in the vials \& the polymeric transdermal patches about $1 \mathrm{~cm}^{2}$ area were fixed over the brim with the help of an adhesive tape. Then the vials were weighed and stored in a humidity chamber at $85 \% \mathrm{RH}$ condition for a period of 24 hours [20]. The vials were removed and weighed at various time intervals like 3, 6 and $24 \mathrm{hr}$ to note down the weight gain. Water Vapour Permeability $=W / A$, Water Vapour Permeability is expressed in $\mathrm{gm} / \mathrm{m}^{2}$ per 24 hours; W is the amount of vapour permeated through the patch $(\mathrm{gm} / 24 \mathrm{hrs})$. A is the surface area of the exposure samples $\left(\mathrm{m}^{2}\right)$.

Drug Content: The prepared patches of $1 \mathrm{~cm} 2$ were cut in three equal parts and kept in a $100 \mathrm{ml} \mathrm{pH} 6.8$ phosphate buffer [21] and stirred for 24 hours and filtered. The filtrate was suitably diluted and determined by UV Spectrophtometer, the drug content then calculated by the mean of three patches.

In Vitro Drug Release: In vitro drug release study of prepared metoprolol succinate transdermal patches was carried out by using USP Paddle Type II dissolution test apparatus at $750 \mathrm{rpm}$ in $900 \mathrm{ml}$ of $\mathrm{pH} 6.8$ phosphate buffer medium at the temperature $37 \pm 0.5^{\circ} \mathrm{C}$ for 24 hours [22]. $5 \mathrm{ml}$ of samples were 
withdrawn at predetermined time interval, filtered, diluted suitably and analysed by UV Spectrophtometer at $223 \mathrm{~nm}$.

Stability Studies: Stability Studies were conducted according to the ICH guidelines [21, 23] by storing the transdermal drug delivery system samples at $40 \pm 0.5^{\circ} \mathrm{C}$ and $75 \pm 5 \%$. Relative humidity for two months. The samples were withdrawn at 0,30 and 60 days and analyze suitability for the drug content.

\section{Result and Discussion:}

$\lambda_{\max }$ Determination: U.V. Spectrophotometer (Shimadzu 1800) was used to determine absorption maxima of the drug Metoprolol Succinate. The $\max$ for drug Metoprolol Succinate in Phosphate Buffer $\mathrm{pH} 6.8$ was found at $223 \mathrm{~nm}$. Figure 1 shows the $\lambda$ $\max _{\text {max }}$ of Metoprolol Succinate in Phosphate Buffer $\mathrm{pH}$ 6.8 .

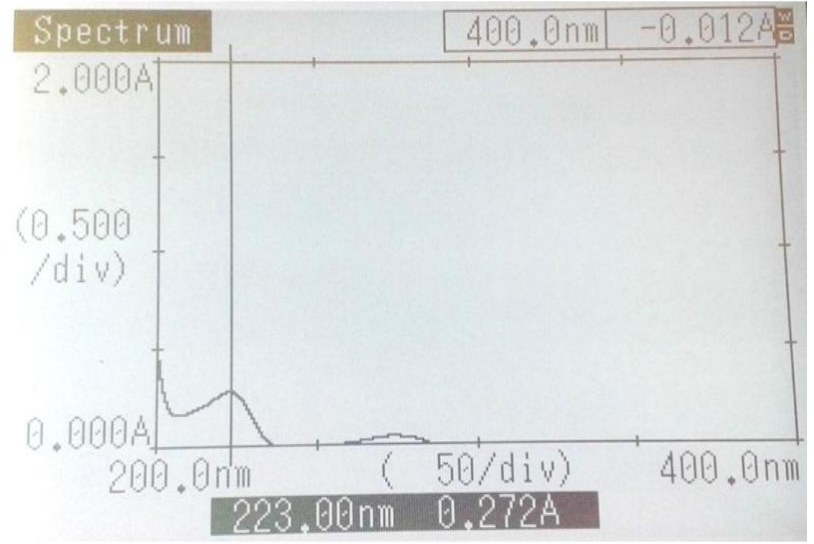

Figure 1: Absorption Maxima of Metoprolol succinate in Phosphate buffer pH 6.8

Calibration curve of Metoprolol succinate: The Calibration curve of drug (Metoprolol Succinate) was prepared in Phosphate Buffer $\mathrm{pH} 6.8$ at 223nm shows the UV absorption. A straight line with $\mathrm{R}^{2}=$ 0.998 for Phosphate Buffer $\mathrm{pH} 6.8$ was found, indicating that the drug follows Beer's law within the specified concentration range.
Table 4: Absorbance of Metoprolol Succinate in phosphate buffer $\mathrm{pH} 6.8$

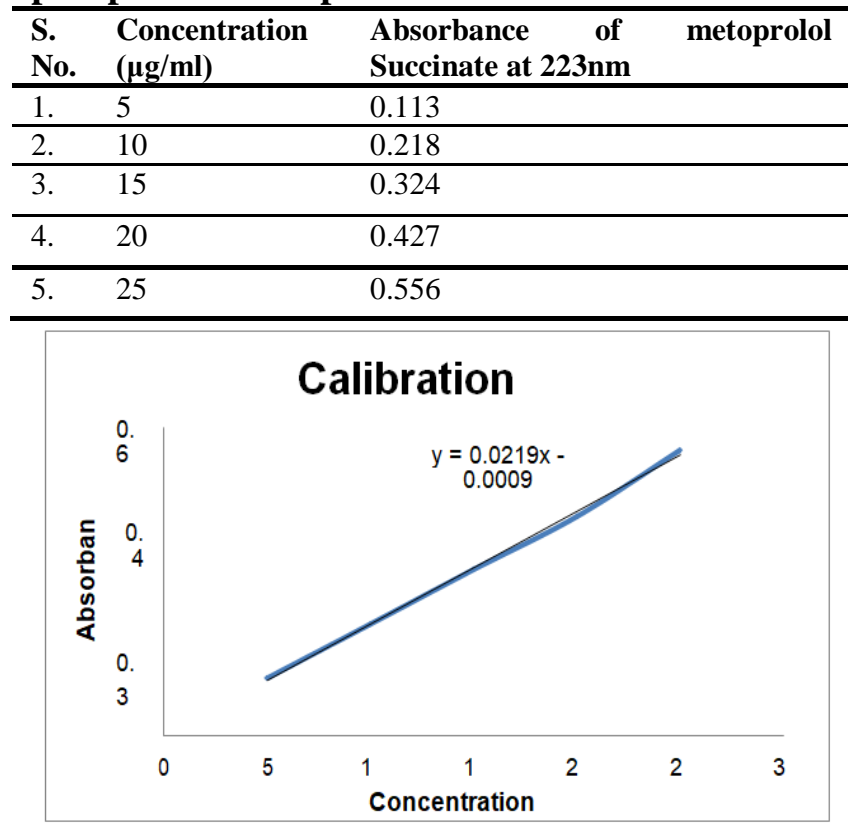

Figure 2: Calibration curve of Metoprolol succinate in phosphate buffer (pH 6.8)

FT-IR Spectroscopy: FT-IR spectrum of the drug sample was obtained by FT- IR (Shimadzu FTIR8101A). The IR spectral analysis of Metoprolol Succinate showed principal peaks observed at wave numbers 3734.48, 3629.37, $2363.34,2341.16,1731.76,1615.09,1516.74$, $1316.18,669.178 \mathrm{~cm}^{-1}$, confirming the purity of Drug.

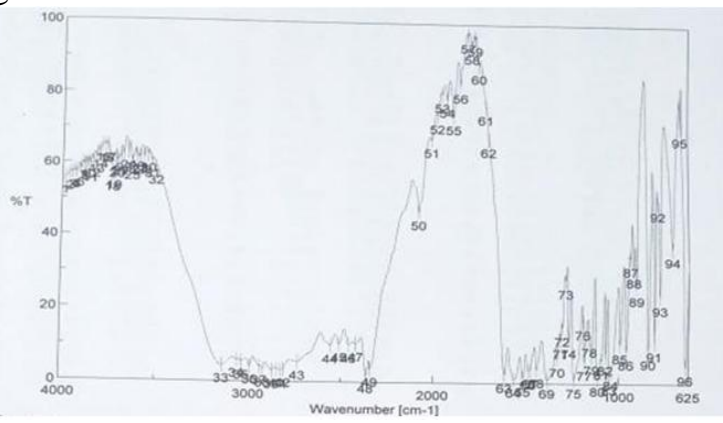

Figure 3: FT-IR Spectra of Metoprolol succinate

Table 5: IR study of drug-polymer mixture

\begin{tabular}{|c|c|c|c|c|c|}
\hline \multirow{2}{*}{$\begin{array}{l}\text { S } \\
\text { No. }\end{array}$} & \multirow{2}{*}{$\begin{array}{l}\text { Functional } \\
\text { present }\end{array}$} & \multicolumn{4}{|c|}{ Wavenumbers $\left(\mathrm{cm}^{-1}\right)$} \\
\hline & & $\begin{array}{l}\text { Metoprolol } \\
\text { succinate }\end{array}$ & $\begin{array}{l}\text { Metoprolol succinate- } \\
\text { HPMC mixture }\end{array}$ & $\begin{array}{l}\text { Metoprolol succinate- } \\
\text { EC mixture }\end{array}$ & $\begin{array}{l}\text { Metoprolol succinate- } \\
\text { HPMC- EC mixture }\end{array}$ \\
\hline 1. & $-\mathrm{NH}_{2}$ & 3734.48 & 3736.4 & 3734.48 & 3734.48 \\
\hline 2. & $-\mathrm{OH}$ & 3629.37 & 3630.34 & 3627.45 & 3625.52 \\
\hline 3. & $-\mathrm{COOH}$ & 2363.34 & 2360.44 & 2360.44 & 2359.48 \\
\hline 4. & $-\mathrm{CH}_{2}-\mathrm{CH}_{2}$ (symmetric) & 2341.16 & 2342.12 & 2341.16 & 2341.16 \\
\hline 5. & - $\mathrm{C}=\mathrm{O}$ (Anhydride) & 1731.76 & 1733.69 & 1731.76 & 1731.76 \\
\hline 6. & $-\mathrm{C}=\mathrm{C}$ & 1615.09 & 1615.09 & 1615.09 & 1616.06 \\
\hline 7. & -C-C (Aromatic) & 1516.74 & 1516.74 & 1516.74 & 1516.74 \\
\hline 8. & $-\mathrm{C}-\mathrm{NO}_{2}$ & 1316.18 & 1316.18 & 1316.18 & 1316.18 \\
\hline 9. & $-\mathrm{C}-\mathrm{H}$ & 669.178 & 669.178 & 669.176 & 669.176 \\
\hline
\end{tabular}


Physicochemical Evaluation of Trandermal Patches:

Table 6: Physicochemical Evaluation of Transdermal Patches

\begin{tabular}{|c|c|c|c|c|c|}
\hline Parameters & F1 & F2 & F3 & F4 & F5 \\
\hline Surface pH & 7.430 .01 & 7.390 .02 & $7.38 \quad 0.01$ & 7.420 .02 & $7.38 \quad 0.02$ \\
\hline Thickness(m m) & $0.17 \quad 0.037$ & 0.190 .018 & $0.18 \quad 0.042$ & 0.170 .031 & $0.18 \quad 0.021$ \\
\hline $\begin{array}{l}\text { Weight Uniformity } \\
\text { (gm) }\end{array}$ & $\begin{array}{ll}1.44 & 0.001 \\
8 & \\
\end{array}$ & $\begin{array}{ll}1.48 & 0.001 \\
4 & \\
\end{array}$ & $\begin{array}{ll}1.43 & 0.001 \\
7 & \\
\end{array}$ & $\begin{array}{l}1.430 .001 \\
5\end{array}$ & $\begin{array}{ll}1.46 & 0.001 \\
7 & \end{array}$ \\
\hline Folding Endurance & 1355.32 & 1324.57 & 1306.92 & 1275.09 & 1254.92 \\
\hline Flatness & $98 \%$ & $97 \%$ & $99 \%$ & $99 \%$ & $98 \%$ \\
\hline$\%$ Moisture Loss & 10.981 .88 & 10.232 .23 & $9.78 \quad 1.46$ & 9.081 .31 & $8.37 \quad 1.29$ \\
\hline$\%$ Moisture Absorption & 8.191 .94 & 7.821 .53 & 7.061 .67 & 6.731 .48 & 5.131 .32 \\
\hline Tensile strength $\left(\mathrm{kg} / \mathrm{mm}^{2}\right)$ & 3.860 .051 & 4.130 .045 & $4.28 \quad 0.045$ & 3.430 .062 & 3.740 .055 \\
\hline Water Vapour Permeability $\left(\mathrm{gm} / \mathrm{m}^{2} / 24 \mathrm{hrs}\right)$ & $12.18 \quad 1.6$ & 12.322 .2 & $11.21 \quad 1.9$ & 11.162 .4 & 12.262 .0 \\
\hline Drug content & $98.99 \quad 0.53$ & $98.97 \quad 0.48$ & 97.890 .65 & 97.960 .38 & $98.93 \quad 0.72$ \\
\hline
\end{tabular}

Mean SD, $\mathrm{n}=5$

In vitro Drug Release: In Vitro Drug Release study indicated that when the polymer concentration increased or changed, the amount of drug permeation increased, initial rapid dissolution of the polymers occurs when the patch is in the contact with the hydrated skin, resulting in the accumulation of high amounts of drug on the skin surface and thus leading to the saturation of the skin with drug molecules at all times. Drug release study of F1 formulation $(97.86 \%)$ was better than the other formulations.

Table 7: Drug release study

\begin{tabular}{|c|c|c|c|c|c|}
\hline \multirow[t]{2}{*}{ Time (hrs) } & \multicolumn{5}{|c|}{ Cumulative percentage drug release (\%) } \\
\hline & F1 & F2 & F3 & F4 & F5 \\
\hline 2 & 13.260 .89 & 13.960 .68 & $12.88 \quad 0.36$ & 12.011 .86 & 11.470 .84 \\
\hline 4 & 20.871 .86 & 24.570 .93 & 24.121 .05 & 25.681 .30 & $26.16 \quad 0.56$ \\
\hline 6 & $36.12 \quad 1.61$ & 31.261 .05 & $32.55 \quad 0.77$ & 34.960 .64 & $30.87 \quad 1.18$ \\
\hline 8 & $45.31 \quad 1.46$ & $43.94 \quad 1.12$ & $40.27 \quad 0.56$ & 39.930 .87 & $34.34 \quad 1.62$ \\
\hline 10 & $58.98 \quad 1.33$ & 53.720 .53 & 49.541 .16 & 43.690 .93 & $40.28 \quad 1.39$ \\
\hline 12 & $69.23 \quad 0.56$ & 66.421 .48 & $63.91 \quad 1.21$ & 63.181 .41 & 58.890 .51 \\
\hline 14 & 76.531 .48 & $74.72 \quad 1.02$ & $73.69 \quad 0.92$ & 71.271 .13 & $69.56 \quad 0.85$ \\
\hline 16 & $82.71 \quad 0.79$ & $80.94 \quad 1.23$ & $76.38 \quad 1.36$ & 74.421 .02 & $72.95 \quad 0.66$ \\
\hline 24 & $97.86 \quad 1.08$ & $94.69 \quad 0.97$ & 93.130 .57 & 90.730 .69 & $88.42 \quad 1.78$ \\
\hline
\end{tabular}

Mean SD, $\mathrm{n}=5$

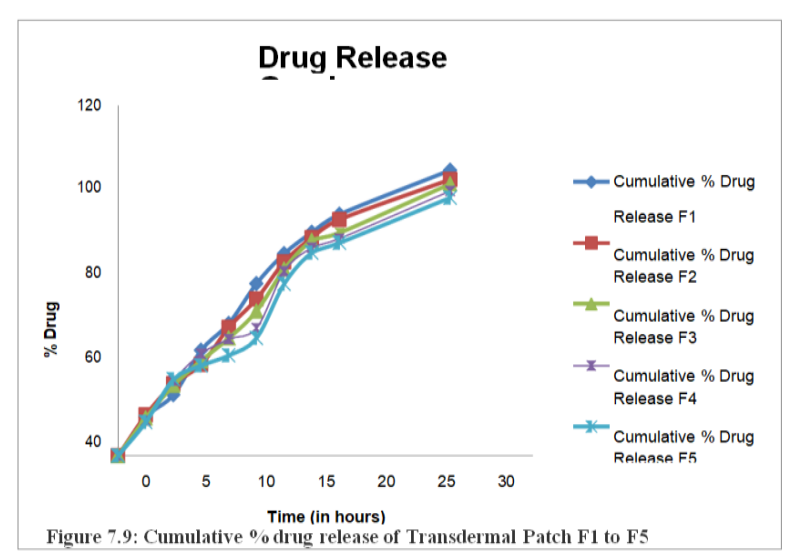

Stability Studies: All the prepared patch formulations were stored at temperature $40^{\circ} \mathrm{C}$ and $75 \% \mathrm{RH}$ for a period of two months and further reevaluated for the drug release and drug content. The results shows that there was no signs of deterioration of patches and no change in drug release and drug content after two months. The results are given in the table 8 .

Table 8: Comparative stability study of different formulation

\begin{tabular}{llllllll}
\hline $\begin{array}{l}\text { S. } \\
\text { No. }\end{array}$ & Batches & $\mathbf{p H}$ & & $\begin{array}{l}\text { Drug } \\
(\boldsymbol{\%})\end{array}$ & release & \multicolumn{2}{l}{$\begin{array}{l}\text { Drug content } \\
(\%)\end{array}$} \\
\hline 1. & F1 & 7.43 & 0.01 & 97.86 & 1.08 & 98.99 & 0.53 \\
\hline 2. & F3 & 7.39 & 0.02 & 94.69 & 0.97 & 98.97 & 0.48 \\
\hline 3. & F5 & 7.38 & 0.01 & 93.13 & 0.57 & 97.89 & 0.65 \\
\hline 4. & F7 & 7.42 & 0.02 & 90.73 & 0.69 & 97.96 & 0.38 \\
\hline 5. & F9 & 7.38 & 0.02 & 88.42 & 1.78 & 98.93 & 0.72 \\
\hline
\end{tabular}

Conclusion:

All the Transdermal Patches formulated were evaluated for their physicochemical evaluation parameters $\mathrm{pH}$, thickness, weight uniformity, folding endurance, moisture uptake, and moisture content, drug content, tensile strength, water vapour permeation, in vitro drug release and stability studies. The five formulations F1 to F5 were 
prepared using polymers in combination Hydroxy Proply methyl Cellulose and Ethyl Cellulose. Dibutyl phthalate used as plasticizer and Dimethyl sulphoxide as a permeation enhance Methanol and chloroform used as solvents. They were used in order to achieve better sustained and controlled drug release over a period of 24 hours. \% Drug release study reveals that from all the five formulations. F1 formulation containing HPMC and $\mathrm{EC}$ in the same ratio emerged as better formulation because it showed better release with sustained effect as compared to other formulations of Metoprolol Succinate. Stability of the prepared patches were observed for two months shows no change in $\mathrm{pH}$, drug content and drug release when calculated.

\section{References:}

1. Agrawal, S.S.; Pruthi, J.K., 2011. Development and evaluation of matrix type transdermal patch of ethinylestradiol and medroxyprogesterone acetate for antiimplantation activity in female Wistar rats. Contraception, Vol 84, 533-538.

2. Pachisia, N.; Agrawal, S.S., 2012. Formulation. Formulation, development and evaluation of transdermal drug delivery system of glimepiride. International Journal of Pharmacy and Pharmaceutical Science Research. Vol 2, Issue 1, pp. 1-8.

3. Amjad; Ehtheshamuddin; Chand, S. Hanifa; Sabreesh, M.; Asia, R.; Kumar, G.S., 2011. Formulation and Evaluation of Transdermal Patches of Atenolol. Advance Research in Pharmaceuticals and Biologicals, Vol 1, Issue 2, pp. 109-19.

4. ]Levin G, Kornfeld J, Patel Y R, and Damon S, Transdermal delivery: Success through a deep understanding of the Skin; 2007, 66-70.

5. Prajapati, S.T.; Patel, C.G.; Patel, C.N., 2011. Formulation and Evaluation of Transdermal Patch of Repaglinide. International Scholarly Research Network Pharmaceutics, pp. 1-9.

6. Chaudhary, H.; Rana, A.C.; Saini, S.; Singh, G., 2011. Formulation and Evaluation of Fexofenadine Hydrochloride Transdermal Patch. Journal of Drug Delivery \& Therapeutics. Vol 2, Issue 5, pp. 20-23.

7. Sharma, S.; Aggarwal, G.; Dhawan, S., 2010. Design and evaluation of Olanzapine transdermal patches containing vegetable oils as permeation enhancers. Der Pharmacia Lettre. Vol 2, Issue 6, pp. 84-98.

8. Dey, S.; Malgope, A., 2010. Preparation of
Carvedilol Transdermal Patch and Effect of Propylene Glycol on Permeation. International Journal of Pharmacy and Pharmaceutical Sciences. Vol 2, Issue 1, pp. 137-143.

9. Lvovich, V.F.; Matthews, E.; Riga, A.T.; Kaza, L., 2010. AC electrokinetic platform for iontophoretic transdermal drug delivery. Journal of Controlled Release, Vol 145, pp. 134-40.

10. Gupta, J.R.D.; Irchhiaya, R.; Garud, N.; Tripathi, P.; Dubey, P; Patel, J.R., 2009. Formulation and evaluation of matrix type transdermal patches of glibenclamide. International Journal of Pharmaceutical Sciences and Drug Research. Vol 1, Issue 1, pp. 46-50.

11. Patel, R.P.; Patel, G.; Baria, A., 2009. Formulation and evaluation of transdermal patch of Aceclofenac. International Journal of Drug Delivery. Vol 1, pp. 41-51.

12. Wahid, A.; Sridhar, B.K.; Shivakumar, S, 2008. Preparation and evaluation of transdermal drug delivery system of etoricoxib using modified chitosan. Indian Journal of Pharmaceutical Sciences. Volume 70, Issue 4, pp. 455-460.

13. Lewis P J, Kohner E M, Petrie A, Dollery C T, Deterioration of glucose tolerance in hypertensive patients on prolonged diuretic treatment; New York, 1998, 564-566.

14. Darwhekar, G.; Jain, D.K.; Patidar, V.K., 2011. Formulation and evaluation of transdermal drug delivery system of clopidogrel bisulfate. Asian Journal of Pharmacy and Life Science. Vol 1, Issue 3, pp. 269-278.

15. Nordquist L, Roxhed N, Griss P, Stemme G, Novel Microneedle patches for active insulin delivery are efficient in maintaining glycaemic control - An initial comparison with subcutaneous administration; Pharmaceutical research; 2007, 24(7): 1381-1389.

16. Mukherjee, Comparative studies between povidone-ethyl cellulose and povidone -eudragit transdermal dexamethasone matrix patches; 2005, 475-83.

17. Gaud, R.S.; Gupta, G.D. Practical Physical Pharmacy. CBS Publishers and Distributors Pvt. Ltd., Reprint 2011.

18. Sharma, V.J.; Amin, P.D., 2013. Design and Optimisation of Extended Release Metoprolol Succinate Formulation Using Melt Granulation Technique. International Journal of Pharmacy and Pharmaceutical Sciences, Vol 5, Issue 3, 
pp. 230-238.

19. Kannan, K.; Manikandan, M.; Periyasamy, G.; Manavalan, R., 2012. Design, Development and Evaluation of Metoprolol Succinate and Hydrochlorothiazide Bilayer Tablets. $J$. Pharm. Sci. \& Res., Vol 4, Issue 3, pp. 18271835.

20. Aggarwal S, Munjal P, Permeation studies of atenolol and metoprolol tartrate from three different matrices for transdermal delivery; Indian J. Pharm. Science; 2007; 69(4): 535-539.

21. .Parivesh S, Dwivedi S, Dwivedi A, design, evaluation, parameters and marketed products of transdermal patches: a review; journal of pharmacy research. 2010; 3(2): 235-240.

22. Sakthikumar, T.; Rajendran, N.N., Natarajan, R., 2012. Formulation and in vitro release characterization of metoprolol succinate extended release tablets. International Journal of Pharmaceutical Sciences and Nanotechnology. Vol 4, Issue 4, pp. 15371543.

23. Rani, K.R.V.; Prakash, S.E.L.; Lathaeswari, R.; Rajeswari, S., 2009. Formulation and development of ER Metoprolaol Succinate Tablets. International Journal of PharmTech Research. Vol.1, Issue 3, pp. 634-638. 